\title{
Thin $\mathrm{TiO}_{2}$ Coatings by ALD Enhance the Cell Growth on $\mathrm{TiO}_{2}$ Nanotubular and Flat Substrates
}

\author{
Martin Motola, Jan Capek, Raul Zazpe, Jana Bacova, Ludek Hromadko, Lenka Bruckova, Siowwoon Ng, \\ Jiri Handl, Zdenek Spotz, Petr Knotek, Kaushik Baishya, Pavlina Majtnerova, Jan Prikryl, Hanna Sopha, \\ Tomas Rousar,* and Jan M. Macak*
}

Cite This: ACS Appl. Bio Mater. 2020, 3, 6447-6456

Read Online

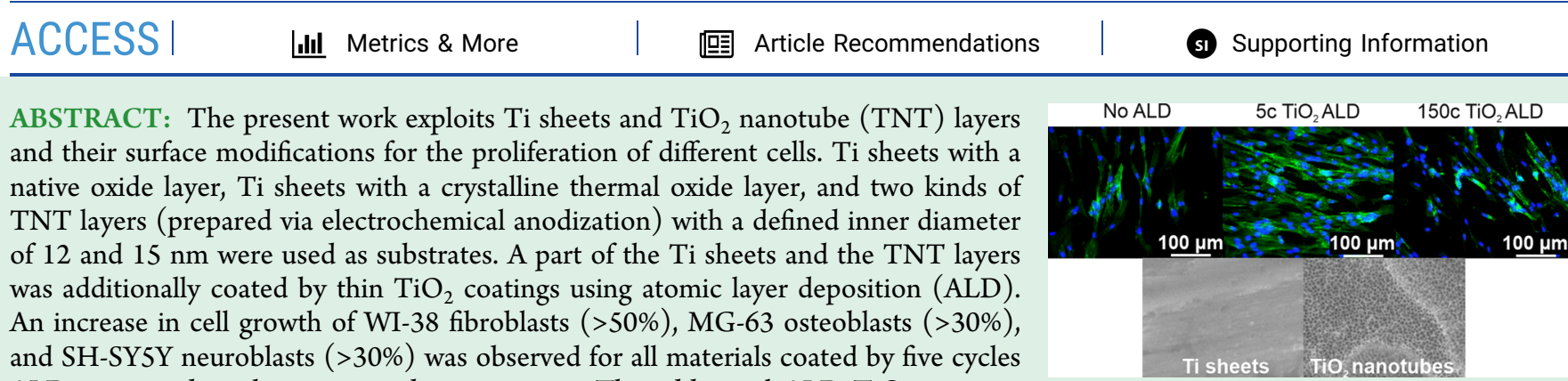
ALD compared to their uncoated counterparts. The additional ALD $\mathrm{TiO}_{2}$ coatings changed the surface composition of all materials but preserved their original structure and protected them from unwanted crystallization and shape changes. The presented approach of mild surface modification by ALD has a significant effect on the materials' biocompatibility and is promising toward application in implant materials.

KEYWORDS: $\mathrm{TiO}_{2}$ nanotube layers, Ti sheets, atomic layer deposition, coatings, cell growth

\section{INTRODUCTION}

$\mathrm{Ti}$ is one of the most widely used materials for medical and dental implants due to its resistance to body fluid effects, low ion release, great tensile strength, flexibility, and high corrosion resistance. ${ }^{1,2}$ The biocompatibility, bioinertness, and high corrosion resistance of $\mathrm{Ti}$ is credited to the presence of a $2-$ $5 \mathrm{~nm}$ thick native oxide layer $\left(\mathrm{TiO}_{2}\right)$ on the $\mathrm{Ti}$ surface. ${ }^{3,4}$ Despite its promising properties, $\mathrm{Ti}$ implants tend to be encapsulated by fibrous tissue in vivo and show a lack of osseointegration, which can lead to infections and implant failure. ${ }^{5}$ The fate of implant materials is not only governed by the bulk of the material (decisive in determining the biological performance) but also by its surface properties, which are crucial factors toward the interactions of the biomaterial with the surrounding tissue. Surface features, such as surface roughness, topography, shape, and orientation of biomaterials, play a vital role in tissue engineering and regenerative medicines ${ }^{6,7}$ and possess a profound influence on the overall cell behavior and phenotypic expression. ${ }^{8-10}$

In general, nanoscale biomaterials offer an improved cell adhesion and proliferation for most cell types compared to their macroscale counterparts. ${ }^{11-16}$ They mimic not only the natural tissue roughness but also possess enhanced adsorption of selected proteins, thus improving the cell functions. ${ }^{16}$ Therefore, to increase the bioactivity of $\mathrm{Ti}$, various surface modifications on $\mathrm{Ti}$ have been performed, including abrasive blasting; ${ }^{17,18}$ acid and laser etching; ${ }^{19-21}$ and additional coating with, e.g., hydroxyapatite, ${ }^{22}$ silver phosphate, ${ }^{23}$ or calcium phosphate. ${ }^{24}$ Numerous studies ${ }^{25-31}$ show a positive effect on cell growth and proliferation by the decorating of different surfaces $\left(\mathrm{Ti}^{30} \mathrm{TiO}_{2},{ }^{3131} \mathrm{ZrO}_{2}{ }^{29}\right.$ or $\mathrm{Mg} / \mathrm{Sr}$ alloy $\left.{ }^{28}\right)$ by atomic layer deposition (ALD) with various coatings $\left(\mathrm{CaCO}_{3}{ }^{31} \mathrm{TiO}_{2}{ }^{30}\right.$ or $\left.\mathrm{ZnO}^{29}\right)$. A study on $\mathrm{L} 929$ murine fibroblasts by Radtke et al. ${ }^{31}$ reports a novel $\mathrm{TiO}_{2}$ nanotubular/hydroxyapatite nanocomposite based on $\mathrm{TiO}_{2}$ nanotubes (TNTs) coated by 100 ALD $\mathrm{CaCO}_{3}$ cycles possessing optimized biocompatible properties. A study by Nazarov et al. ${ }^{30}$ on MC3T3-E1 murine osteoblasts reports improved properties of Ti implants for osseointegration after 400 ALD $\mathrm{TiO}_{2}$ cycles. Ti-based implants coated by $2500 \mathrm{ALD} \mathrm{TiO}_{2}$ cycles, reported by Liu et al., ${ }^{26}$ stimulate primary osteoblast adhesion and proliferation and suppress dermal fibroblast adhesion and proliferation compared to untreated Ti-based implants. Also, adhesion of MG-63 cells was improved on Ti surfaces after $400 \mathrm{ALD} \mathrm{TiO}_{2}$ cycles. ${ }^{25}$ Nevertheless, all of these reports use a relatively high number of ALD cycles (1002500), which is disadvantageous from several points of view: (i) the material loses its original structure and becomes fully

Received: July 14, 2020

Accepted: August 17, 2020

Published: August 18, 2020 
covered by the additional ALD coating, which is in particular undesirable for $\mathrm{TiO}_{2}$ nanotubes with their unique structure, (ii) the risk of delamination due to the low adhesion of rather thick ALD coatings to the substrate, and (iii) economic and environmental aspects.

$\mathrm{TiO}_{2}$ nanotube (TNT) layers are long recognized as excellent biocompatible material owing to their low cytotoxicity, high stability, and antibacterial properties. ${ }^{32,33}$ An advantage of TNT layers is that they can be directly grown, with controllable geometry, on $\mathrm{Ti}$ substrates via electrochemical anodization. ${ }^{34}$ Due to their already mentioned excellent biocompatibility, controllable dimensions, surface chemistry, and large surface-to-volume ratio, TNT layers have been shown to be a superior platform for local drug delivery. ${ }^{35-37}$ By adjusting the morphology of TNT layers, the release kinetics of specific drugs can be tailored to achieve stable and sustained release. ${ }^{35}$ As they possess good hemocompatibility and anticoagulation characteristics, TNT layers are promising for vascular implants and biomedical applications due to increased osteoblast cell adhesion and proliferation, ${ }^{15,38,39}$ increased growth of hydroxyapatite, ${ }^{38,39}$ enhanced protein adsorption, ${ }^{40}$ and improved cellular behavior and tissue integration. ${ }^{41}$ Vitality, proliferation, and motility of mesenchymal stem cells (MSCs) and their differentiation to bone-forming cells are severely influenced by the TNTs' surface topography and is reported as follows: adhesion, proliferation, migration, and differentiation are very strong for TNT layers with diameters of around $15 \mathrm{~nm}$, while a strong decay in cell activity is observed for TNT layers with diameters larger than $50 \mathrm{~nm}^{42-44}$

For the majority of biomedical applications, an amorphous state of a material is preferred, and these materials have been frequently used in an aqueous environment. However, soaking of amorphous TNT layers in a water bath transforms them into a polycrystalline anatase structure via the so-called water annealing effect ${ }^{32,45,46}$ accompanied by significant morphological changes. Recently, we reported ${ }^{45}$ a successful approach to prevent the water annealing effect by additional utilization of thin $\mathrm{TiO}_{2}$ coatings by ALD to protect TNT layers against morphological changes during prolonged water soaking.

In the present work, we aimed to estimate the relation between ALD $\mathrm{TiO}_{2}$ coatings of flat and nanotubular $\mathrm{TiO}_{2}$ surfaces and cell growth on these modified surfaces. Thus, commercial $\mathrm{Ti}$ sheets and anodic TNT layers were coated by additional $\mathrm{TiO}_{2}$ coatings using ALD. The morphology and composition of all surfaces were investigated by scanning electron microscopy (SEM), X-ray photoelectron spectroscopy (XPS), X-ray diffraction (XRD), atomic force microscopy (AFM), and digital holographic microscopy (DHM). Then, the cell adhesion and growth using three cell lines of different origin and cell morphology (WI-38 fibroblasts, MG-63 osteoblasts, and SH-SY5Y neuroblasts) were investigated on the uncoated and ALD $\mathrm{TiO}_{2}$-coated substrates.

\section{EXPERIMENTAL SECTION}

2.1. Materials Synthesis and Characterization. Different kinds of Ti sheets and TNT layers were used to study the cell proliferation: (1) $\mathrm{Ti}$ sheets with a native amorphous oxide layer (a-TiS), (2) $\mathrm{Ti}$ sheets with a crystalline thermal oxide layer (c-TiS), and (3) $\mathrm{TiO}_{2}$ nanotube (TNT) layers with two different inner diameters of $\sim 12$ and $\sim 15 \mathrm{~nm}$ (yielding TNT 12 and TNT 15 , respectively).

Prior to all experiments, the Ti sheets (Sigma-Aldrich, $0.127 \mathrm{~mm}$ thick, $99.7 \%$ purity) were cut in square pieces $(1.5 \times 1.5 \mathrm{~cm})$, then degreased by sonication in isopropanol, acetone, and isopropanol and dried by a nitrogen jet.

To obtain c-TiS, the a-TiS were annealed in a muffle oven at 400 ${ }^{\circ} \mathrm{C}$ for $1 \mathrm{~h}$. This was done to achieve a crystalline thermal oxide layer on the surface of c-TiS compared to the amorphous native oxide layer present on the as-purchased a-TiS.

TNT layers were prepared via electrochemical anodization of aTiS. The TNT layers were grown at room temperature in an electrochemical cell with a circular opening exposing $1 \mathrm{~cm}^{2}$ of the a$\mathrm{TiS}$ to the electrolyte. A platinum foil was used as a counter electrode. Anodization was carried out using a high-voltage potentiostat (HEIDEN, EA-PSI 9200-15, Germany) attached to a digital multimeter (Keithley 2100) in a glycerol-based electrolyte containing $50 \mathrm{vol} \%$ water and $0.27 \mathrm{M} \mathrm{NH}_{4} \mathrm{~F}$ at 2 and $4 \mathrm{~V}$ for $3 \mathrm{~h}$ to obtain TNT 12 and TNT 15, respectively. After anodization, the TNT layers were sonicated in isopropanol and dried in air.

Atomic layer deposition (ALD, TFS200, Beneq) of $\mathrm{TiO}_{2}$ was carried out at $300{ }^{\circ} \mathrm{C}$ using $\mathrm{TiCl}_{4}$ (electronic grade $99.9998 \%$, STREM) as the titanium precursor and Milli-pore deionized water $\left(18 \mathrm{M} \Omega\right.$ ) as the oxygen source. High-purity $\mathrm{N}_{2}$ (99.9999\%) was the carrier and purging gas at a flow rate of 400 standard cubic centimeters per minute $(\mathrm{sccm})$. Under these deposition conditions, one growth ALD cycle was defined by the following sequence: $\mathrm{TiCl}_{4}$ pulse $(500 \mathrm{~ms})-\mathrm{N}_{2}$ purge $(3 \mathrm{~s})-\mathrm{H}_{2} \mathrm{O}$ pulse $(500 \mathrm{~ms})-\mathrm{N}_{2}$ purge $(4$ s). Part of the Ti sheets and TNT layers were coated by $\mathrm{TiO}_{2}$ by applying 5 and $150 \mathrm{ALD}$ cycles. Corresponding samples are later denoted as " $+5 \mathrm{c} \mathrm{TiO}_{2}$ " or " $+150 \mathrm{c} \mathrm{TiO}_{2}$ ", respectively. Based on our previous experience and results, ${ }^{45,47}$ the nominal thickness of the ALD $\mathrm{TiO}_{2}$ coating is $0.275 \mathrm{~nm}$ and $8.25 \mathrm{~nm}$ on flat and sufficiently hydroxylated $\mathrm{TiO}_{2}$ substrates.

The surface morphology of all $\mathrm{Ti}$ sheets and TNT layers was characterized using a field-emission scanning electron microscopy (FE-SEM, JEOL JSM 7500F). The morphological parameters were evaluated by statistical analyses of SEM images using proprietary Nanomeasure software.

The roughness of all Ti sheets and TNT layers was determined using a digital holographic microscope (DHM, DHMR1000, Lyncee $\mathrm{Tec}$, Switzerland) operating at $785 \mathrm{~nm}$ in reflection configuration on the scale of $170 \mu \mathrm{m}$ and according to our previous work, ${ }^{48}$ by atomic force microscopy (AFM, Solver Pro-M, NT-MDT, Russia) on an area of $5 \times 5 \mu \mathrm{m}^{2}$.

The structure of all Ti sheets and TNT layers was characterized by X-ray diffraction (XRD, PANalytical Empyrean diffractometer) using a Cu X-ray tube and a scintillation detector Pixcel ${ }^{3 \mathrm{D}}$, respectively. The $\mathrm{XRD}$ measurements were performed in the $2 \theta$ range of $5-70^{\circ}$, with a step size of $0.026^{\circ}$. Grazing incidence XRD (GI-XRD) was carried out using a $3 \mathrm{~kW}$ diffractometer Smartlab (Rigaku) equipped with a detector D-tex Ultra. The diffractometer was set up in parallel beam geometry and asymmetric grazing incidence mode with the angle of the incident beam set to $0.5^{\circ}$ using a Cu lamp (30 mA and $40 \mathrm{kV}$ ).

The composition of all Ti sheets and TNT layers was evaluated by $\mathrm{X}$-ray photoelectron spectroscopy (XPS, Kratos AXIS Supra) using a monochromatic Al K $\alpha(1486.7 \mathrm{eV}) \mathrm{X}$-ray source. The X-ray source was operated at $225 \mathrm{~W}$. The binding energy scale was referenced to adventitious carbon $(284.8 \mathrm{eV})$. No charging neutralizer was used during the measurements. The spectra were fitted using the Shirleytype background by CasaXPS software. The quantitative analysis was performed using the elemental sensitivity factors provided by the manufacturer

2.2. Cell Culture. Human osteoblast-like cells (MG-63, ATCC No. CRL-1427) and human lung fibroblast cells (WI-38, ATCC No. CCL-75) were cultured in a modified Eagle's medium (Sigma) with $10 \%(\mathrm{v} / \mathrm{v})$ fetal bovine serum (Gibco) and $50 \mu \mathrm{g} / \mathrm{mL}$ penicillinstreptomycin solution (Gibco). Human neuroblastoma cells (SHSY5Y, ATCC No. CRL-2266) were cultured in supplemented Dulbecco's modified Eagle's medium (DMEM/F12 = 1:1; Sigma) with $15 \%(\mathrm{v} / \mathrm{v})$ fetal bovine serum (Gibco) and $50 \mu \mathrm{g} / \mathrm{mL}$ penicillinstreptomycin solution (Gibco), followed by incubation in an atmosphere of $5 \% \mathrm{CO}_{2}$ at $37{ }^{\circ} \mathrm{C}$. The cells were proven to be 
mycoplasma-free and the STR analysis confirmed the origin of all three cell lines.

2.3. Fluorescence Staining and Cell Counting. All Ti sheets and TNT layers were sterilized in $70 \%$ ethanol for $30 \mathrm{~min}$, washed with phosphate-buffered saline (PBS) and deionized water, and dried. Then, the foils were placed into eight-well chamber slides. Briefly, 200 $\mu \mathrm{L}$ of a suspension of MG-63, WI-38, and SH-SY5Y cells with a density of $7 \times 10^{3} / \mathrm{mL}, 2 \times 10^{4} / \mathrm{mL}$, and $2 \times 10^{4} / \mathrm{mL}$, respectively, was added into each well of a chamber slide and the cells were seeded and cultured for $24 \mathrm{~h}$. To visualize the cells, we used two fluorescence probes: Hoechst 33258 (Sigma) to stain the cell nucleus and phalloidin-fluorescein isothiocyanate (FITC) (Sigma) to stain actin filaments in cells. After $24 \mathrm{~h}$ of seeding, the cultured cells were fixed by $3.7 \%$ formaldehyde $\left(5 \mathrm{~min} ; 37^{\circ} \mathrm{C}\right.$; dark $)$ and permeabilized by $0.1 \%$ Triton X $100\left(15 \mathrm{~min} ; 37{ }^{\circ} \mathrm{C}\right.$; dark). Then, $100 \mu \mathrm{L}$ of phalloidin-FITC was incubated for $30 \mathrm{~min}$ at $37{ }^{\circ} \mathrm{C}$ to obtain a final concentration of $1 \mu \mathrm{M}$ phalloidin-FITC in a well. After incubation, 10 $\mu \mathrm{L}$ of Hoechst 33258 solution was added to the cells for $10 \mathrm{~min}$. The final concentration of Hoechst 33258 in a well was $2 \mu \mathrm{g} / \mathrm{mL}$. After the loading process, the cells were washed two times with PBS. The actin filaments (FITC filter, 480/30 nm) and cell nuclei (DAPI filter, 375/ $28 \mathrm{~nm}$ ) were observed with an Eclipse 80i fluorescence microscope (Nikon, Japan). The number of cells grown on the surface was counted minimally from 20 fields of view using NIS-Elements AR (Nikon, Japan). All experiments were repeated 3-5 times independently. The number of cell nuclei was related to $1 \mathrm{~mm}^{2}$ and expressed as mean \pm standard error of mean (SEM).

\section{RESULTS AND DISCUSSION}

3.1. Surface, Structure, and Composition Characteristics. Surface properties along with the crystallinity and

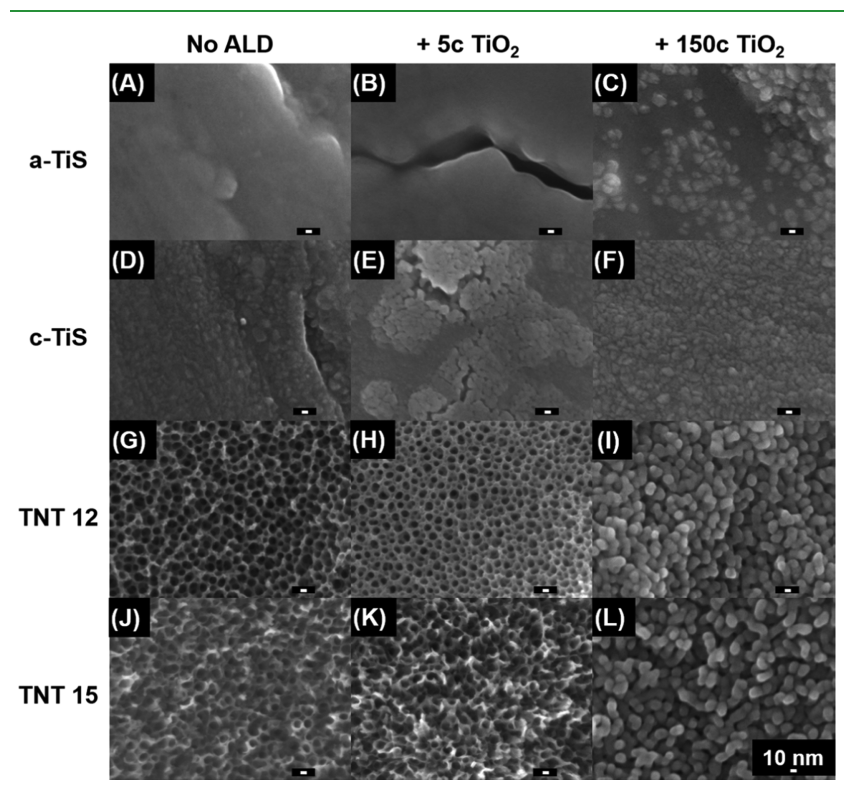

Figure 1. SEM top-view images of (A, B, C) Ti sheets with a native amorphous oxide layer (a-TiS), (D, E, F) Ti sheets with a crystalline thermal oxide layer (c-TiS), $(\mathrm{G}, \mathrm{H}, \mathrm{I}) \mathrm{TiO}_{2}$ nanotube (TNT) layers with an inner diameter of $\sim 12 \mathrm{~nm}$, and (J, K, L) TNT layers with an inner diameter of $\sim 15 \mathrm{~nm}$. The left column shows uncoated samples, the middle column $+\mathrm{ALD} 5 \mathrm{c} \mathrm{TiO}_{2}$, and the right column + ALD $150 \mathrm{c} \mathrm{TiO}_{2}$.

composition of a material are of immense importance for cell attachment and proliferation. Therefore, characterization of uncoated and $\mathrm{ALD} \mathrm{TiO}_{2}$-coated $\mathrm{Ti}$ sheets and TNT layers was performed using SEM, XRD, XPS, AFM, and DHM to study

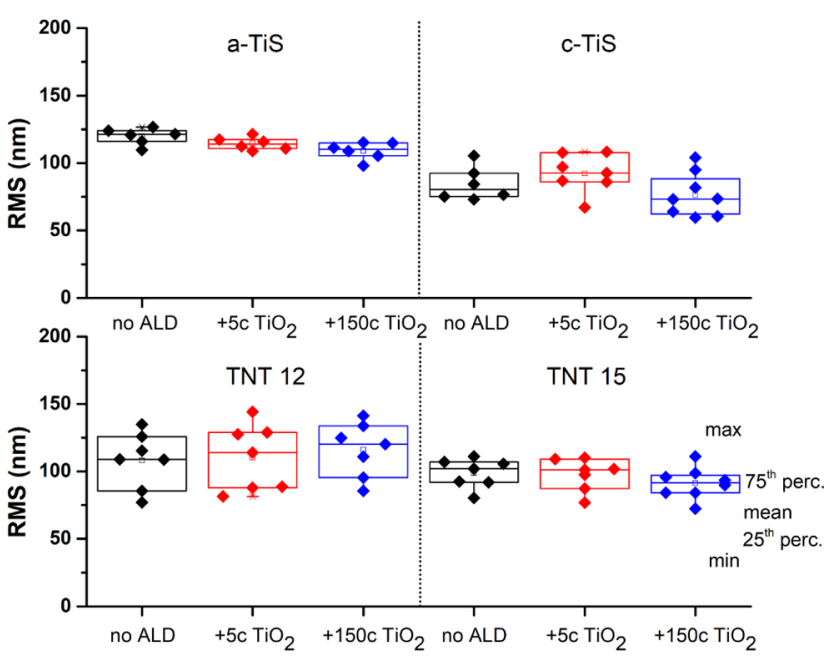

Figure 2. Roughness values (root mean square, RMS) obtained by DHM in the form of the box-plot describing mean (open square); 1st and 3rd quantile (box); and $\mathrm{min} / \mathrm{max}$ values (whisker) of uncoated and ALD-coated ( $5 \mathrm{c}$ and $150 \mathrm{c} \mathrm{TiO}_{2}$ ) Ti sheets with a native oxide layer (a-TiS), Ti sheets with a crystalline thermal oxide layer (c-TiS), and $\mathrm{TiO}_{2}$ nanotube (TNT) layers with inner diameters of 12 and 15 $\mathrm{nm}$ (TNT 12 and TNT 15, respectively). The full rectangle reflects the experimental RMS value for each line.

the changes in their morphology, structure, composition, and surface roughness.

Representative top-view SEM images of all $\mathrm{Ti}$ sheets and $\mathrm{TiO}_{2}$ nanotube (TNT) layers are shown in Figure 1. The first column of Figure 1 shows the uncoated surfaces, i.e., from top to bottom, $\mathrm{Ti}$ sheets with a native oxide layer (a-TiS), Ti sheets with a crystalline thermal oxide layer (c-TiS), and TNT layers with inner diameters of $\sim 12$ and $\sim 15 \mathrm{~nm}$ (TNT 12 and TNT 15 , respectively).

The Ti sheets (a-TiS and c-TiS) are rather flat with the typical morphology of commercial Ti sheets with visible rolling lines as a result of the manufacturing process (Figure 1A,D). The surface morphology of c-TiS does not significantly change after annealing compared to a-TiS. By tailoring the anodization conditions, vertically oriented TNT layers were obtained with inner diameters of $\sim 12 \mathrm{~nm}$ (TNT 12, Figure $1 \mathrm{G}$ ) and $\sim 15 \mathrm{~nm}$ (TNT 15, Figure 1J). The TNT layer thickness of $\sim 50$ and $\sim 300 \mathrm{~nm}$ was determined from cross-section images (Figure S1) of TNT 12 and TNT 15, respectively. More detailed topview SEM images of the obtained nanotubular surfaces indicate well-controlled diameters and an open top of the TNTs (Figure S2).

The SEM images in the second and third column of Figure 1 show surfaces of Ti sheets and TNT layers coated with 5 and $150 \mathrm{ALD} \mathrm{TiO}_{2}$ cycles, respectively. After $5 \mathrm{ALD} \mathrm{TiO}_{2}$ cycles, the surface of a-TiS $+5 \mathrm{c} \mathrm{TiO}_{2}$ and $\mathrm{c}-\mathrm{TiS}+5 \mathrm{c} \mathrm{TiO}_{2}$ became visibly smoother (Figure $1 \mathrm{~B}, \mathrm{E}$ ) and the original rolling lines of the titanium sheets were covered with the additional ALD $\mathrm{TiO}_{2}$ coating. It was not possible to observe the newly added ALD $\mathrm{TiO}_{2}$ coating after 5 ALD cycles on any of the TNT layers (TNT $12+5 \mathrm{c} \mathrm{TiO}_{2}$, Figure $1 \mathrm{H}$, and TNT $15+5 \mathrm{c} \mathrm{TiO}$, Figure $1 \mathrm{~K}$ ) by SEM due to their extremely small thicknesses (the nominal thickness of the coating is approx. $0.3 \mathrm{~nm}$ ). Thus, the morphology is comparable with the uncoated TNT layers (TNT 12, Figure 1G, and TNT 15, Figure 1J). However, the successful coating of TNT layers by additional ALD $\mathrm{TiO}_{2}$ coating was confirmed by XPS, which is discussed later. Based 
Table 1. XPS Data Showing the Chemical Composition (Atomic \%) of Uncoated and ALD $\mathrm{TiO}_{2}-\mathrm{Coated}\left(5 \mathrm{c}\right.$ and $\left.150 \mathrm{c} \mathrm{TiO}_{2}\right) \mathrm{Ti}$ Sheets with a Native Oxide Layer (a-TiS), Ti Sheets with a Crystalline Thermal Oxide Layer (c-TiS), and $\mathrm{TiO}_{2} \mathrm{Nanotube}$ (TNT) Layers with Inner Diameters of 12 and 15 nm (TNT 12 and TNT 15, Respectively)

\begin{tabular}{|c|c|c|c|c|c|c|}
\hline \multirow[b]{2}{*}{ sample } & \multicolumn{6}{|c|}{ chemical composition (atom \%) } \\
\hline & O 1s & C 1s & $\mathrm{N} 1 \mathrm{~s}$ & F 1s & Ti $2 p$ & other \\
\hline $\mathrm{a}-\mathrm{TiS}$ & 38.95 & 39.85 & 2.08 & & 9.16 & 10.81 \\
\hline $\mathrm{a}-\mathrm{TiS}+5 \mathrm{c} \mathrm{TiO}_{2}$ & 42.33 & 36.81 & 2.75 & & 13.21 & 2.91 \\
\hline $\mathrm{a}-\mathrm{TiS}+150 \mathrm{c} \mathrm{TiO}_{2}$ & 43.48 & 31.56 & 1.15 & & 14.98 & 9.39 \\
\hline c-TiS & 49.25 & 27.64 & 0.93 & & 18.18 & 4.00 \\
\hline$c-\mathrm{TiS}+5 \mathrm{c} \mathrm{TiO}_{2}$ & 51.96 & 24.63 & 1.25 & & 19.45 & 2.93 \\
\hline $\mathrm{c}-\mathrm{TiS}+150 \mathrm{c} \mathrm{TiO}_{2}$ & 52.18 & 22.84 & 1.17 & & 30.80 & 2.78 \\
\hline TNT 12 & 39.95 & 41.00 & 2.08 & 2.77 & 14.19 & \\
\hline $\mathrm{TNT} 12+5 \mathrm{c} \mathrm{TiO}_{2}$ & 45.37 & 36.27 & 2.24 & 0.43 & 15.70 & \\
\hline $\mathrm{TNT} 12+150 \mathrm{c} \mathrm{TiO}_{2}$ & 49.95 & 25.93 & 1.41 & & 19.67 & 3.04 \\
\hline TNT 15 & 36.42 & 42.17 & 1.78 & 2.66 & 15.79 & 2.12 \\
\hline TNT $15+5 \mathrm{c} \mathrm{TiO}_{2}$ & 36.36 & 41.23 & 1.88 & 0.34 & 16.60 & 2.14 \\
\hline TNT $15+150 c \mathrm{TiO}_{2}$ & 44.16 & 28.10 & 1.42 & & 22.51 & 3.48 \\
\hline
\end{tabular}

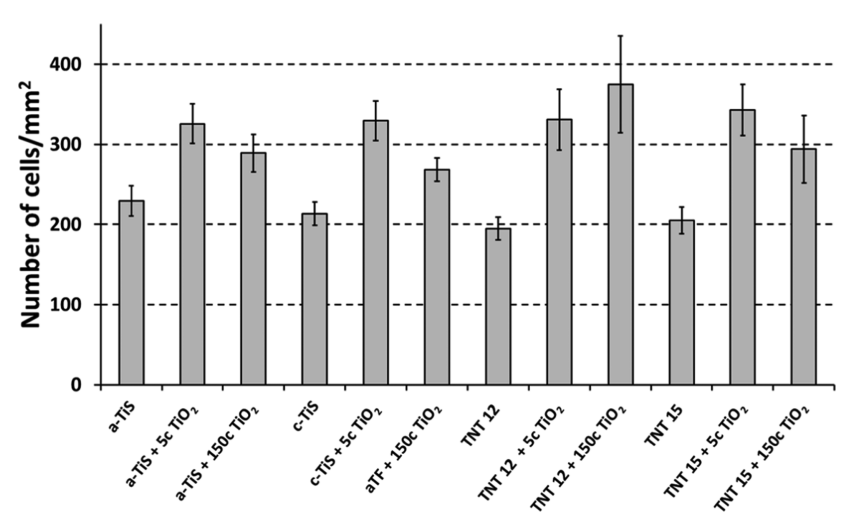

Figure 3. Density of WI-38 cells grown for $24 \mathrm{~h}$ on uncoated and ALD-coated (5c and $150 \mathrm{c} \mathrm{TiO}_{2}$ ) $\mathrm{Ti}$ sheets with a native oxide layer (a-TiS), Ti sheets with a crystalline thermal oxide layer (c-TiS), and $\mathrm{TiO}_{2}$ nanotube (TNT) layers with inner diameters of 12 and $15 \mathrm{~nm}$ (TNT 12 and TNT 15, respectively). Data are presented as mean \pm SEM.

on our previous studies, ${ }^{45,47}$ we did not expect any island-like growth or any nucleation issues for the ALD $\mathrm{TiO}_{2}$ coating, in particular as we grow ALD $\mathrm{TiO}_{2}$ coatings on $\mathrm{TiO}_{2}$ substrates. Significant alterations on the surface morphologies of all $\mathrm{Ti}$ sheets and TNT layers were observed after applying 150 ALD $\mathrm{TiO}_{2}$ cycles, which corresponds to an approx. $8 \mathrm{~nm}$ thick ALD $\mathrm{TiO}_{2}$ coating, due to the growth of $\mathrm{TiO}_{2}$ crystals on the surfaces. Details are discussed later in the XRD section. Moreover, in the case of TNT $12+150 \mathrm{c} \mathrm{TiO}_{2}$ (Figure 1I) and TNT $15+150 \mathrm{c} \mathrm{TiO}_{2}$ (Figure $1 \mathrm{~L}$ ), a significant decrease in the inner tube diameter is observed and a part of the nanotubes is clogged by the additional $\mathrm{TiO}_{2}$ coating. The clogging of TNT 15 after $150 \mathrm{ALD} \mathrm{TiO}_{2}$ cycles is depicted in Figure S3 for TNT layers.

Additional information about the surface morphology alterations of uncoated and $\mathrm{ALD} \mathrm{TiO}_{2}$-coated $\mathrm{Ti}$ sheets and TNT layers was acquired by DHM and AFM profilometric measurements. The corresponding results are discussed in detail in the Supporting Information (Table S1, Figures S4 and S5). Briefly, the root mean square (RMS) values obtained by DHM represent statistically the roughness deviation calculated for each line from Figure S4 and are statistically processed into a box-plot (Figure 2). Overall, the highest DHM RMS values were obtained for uncoated a-TiS (mean DHM RMS $\sim 121$ $\mathrm{nm}$ ) while uncoated c-TiS were the smoothest substrates (DHM RMS $\sim 85 \mathrm{~nm}$ ). DHM RMS values of $\sim 108$ and $\sim 99$ nm were obtained for TNT 12 and TNT 15, respectively. After 5 and $150 \mathrm{ALD} \mathrm{TiO}_{2}$ cycles, the relative roughness of $\mathrm{Ti}$ sheets and TNT layers was not statistically affected by the additional ALD $\mathrm{TiO}_{2}$ coating compared to that of the uncoated ones. Nevertheless, based on AFM (Figure S5 and Table S1), the difference in the surface features is pronounced for $\mathrm{Ti}$ sheets and TNT layers. a-TiS shows surface cracks as a result of the manufacturing process. However, the c-TiS samples are covered by $\mathrm{TiO}_{2}$ grains due to expansion of the oxide during thermal annealing at $400{ }^{\circ} \mathrm{C}$ (such a thermal volume expansion is expressed by the Pilling-Bedworth ratio $\left.{ }^{49}\right)$. In the case of TNT layers, irregular pits (approx. $1 \times 1 \mu \mathrm{m}^{2}$ ) are present on the surface of the TNT layers as a result of the anodization process (i.e., formation and dissolution of $\mathrm{TiO}_{2}$ by the voltageinduced etching of $\mathrm{Ti}$ by fluoride ions). ${ }^{50}$ Nevertheless, the trend in the AFM RMS values does not significantly change for uncoated and ALD $\mathrm{TiO}_{2}$-coated $\mathrm{Ti}$ sheets and TNT layers, which is in good correlation with DHM profilometric measurements.

The phase composition of uncoated and ALD $\mathrm{TiO}_{2}$-coated Ti sheets and TNT layers was studied by XRD. The results are discussed in detail in the Supporting Information (Figures S7S10). In sum, in the case of uncoated $\mathrm{Ti}$ sheets and TNT layers, the surface of a-TiS consists of an amorphous native $\mathrm{TiO}_{2}$ layer, the surface of c-TiS consists of a crystalline $\mathrm{TiO}_{2}$ layer, and the TNT layers are of amorphous nature. After 5 ALD $\mathrm{TiO}_{2}$ cycles, the phase composition of all $\mathrm{Ti}$ sheets and TNT layers remained amorphous with no significant changes in the phase composition. However, after $150 \mathrm{ALD} \mathrm{TiO}_{2}$ cycles, crystallization of the additional ALD $\mathrm{TiO}_{2}$ coating proceeded. Indeed, $\mathrm{TiO}_{2}$ crystallites were visible on the surface of all $\mathrm{Ti}$ sheets and TNT layers coated by $150 \mathrm{ALD} \mathrm{TiO}_{2}$ cycles (Figure 1, third column). The reason for this is that the temperature used during the ALD process $\left(300{ }^{\circ} \mathrm{C}\right)$ is sufficient to transfer the amorphous $\mathrm{TiO}_{2}$ to crystalline anatase $\mathrm{TiO}_{2}$ with space group $\mathrm{P}_{2} / m n m$ (ICCD 01-086-1157). . $^{51,52}$ This crystallization occurs only in the case of a thicker $\mathrm{TiO}_{2}$ coating (approx. $8 \mathrm{~nm}$ after $150 \mathrm{ALD} \mathrm{TiO}_{2}$ cycles) where the amorphous-to-anatase nucleation occurred, whereas in a thinner $\mathrm{TiO}_{2}$ coating (approx. $0.3 \mathrm{~nm}$ after $5 \mathrm{ALD} \mathrm{TiO}_{2}$ cycles), nucleation did not occur. This is due to physical constraints against crystallization imposed by a very low 


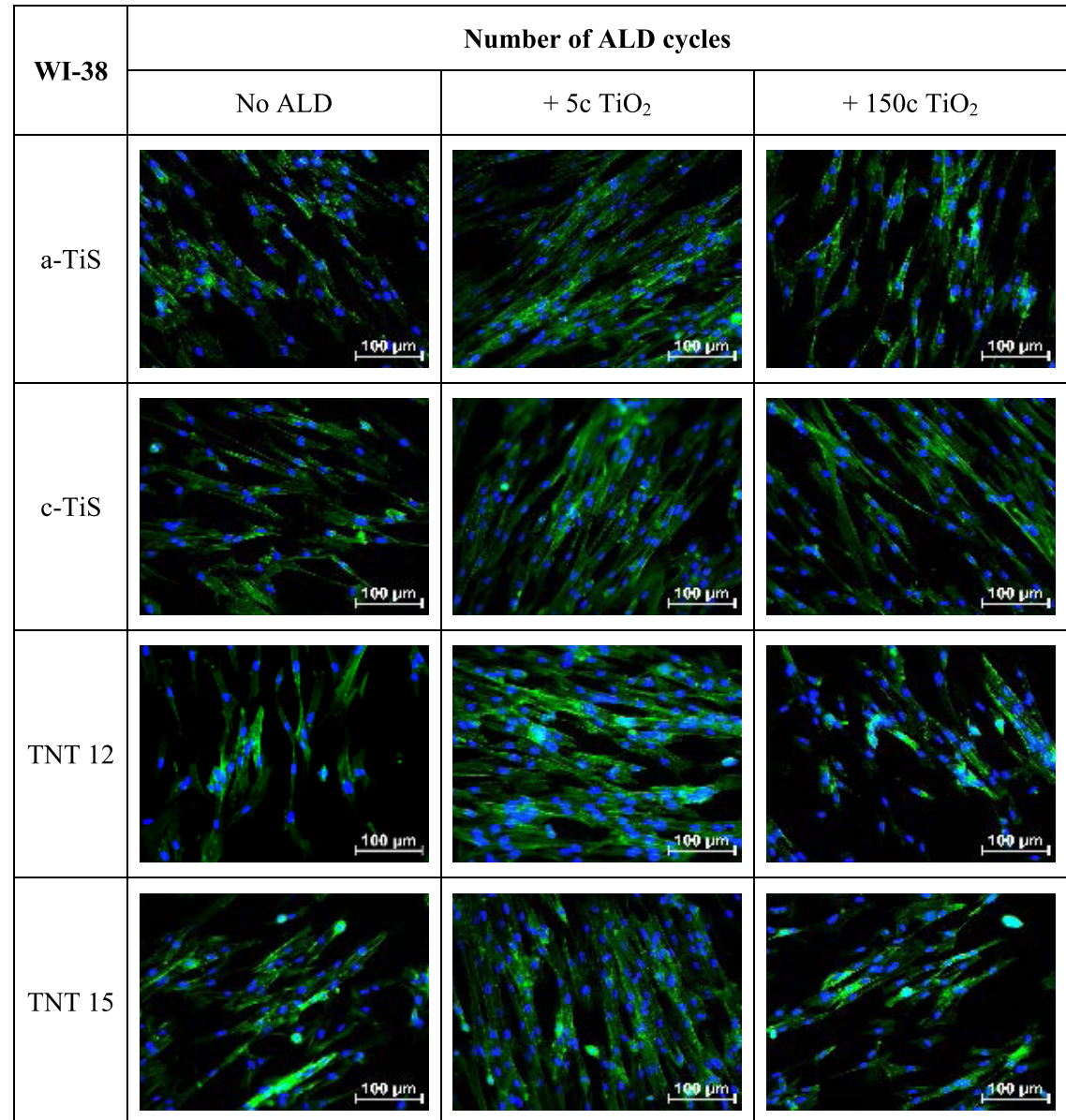

Figure 4. Photomicrographs of WI-38 cells grown for $24 \mathrm{~h}$ on uncoated and ALD-coated $\left(5 \mathrm{c}\right.$ and $\left.150 \mathrm{c} \mathrm{TiO}_{2}\right)$ Ti sheets with a native oxide layer (a$\mathrm{TiS}$ ), Ti sheet with a crystalline thermal oxide layer (c-TiS), and $\mathrm{TiO}_{2}$ nanotube (TNT) layers with inner diameters of 12 and $15 \mathrm{~nm}$ (TNT 12 and TNT 15, respectively). The cells were stained using the Hoechst 33258 dye (blue, nuclei) and phalloidin-FITC probe (green, actin filaments).

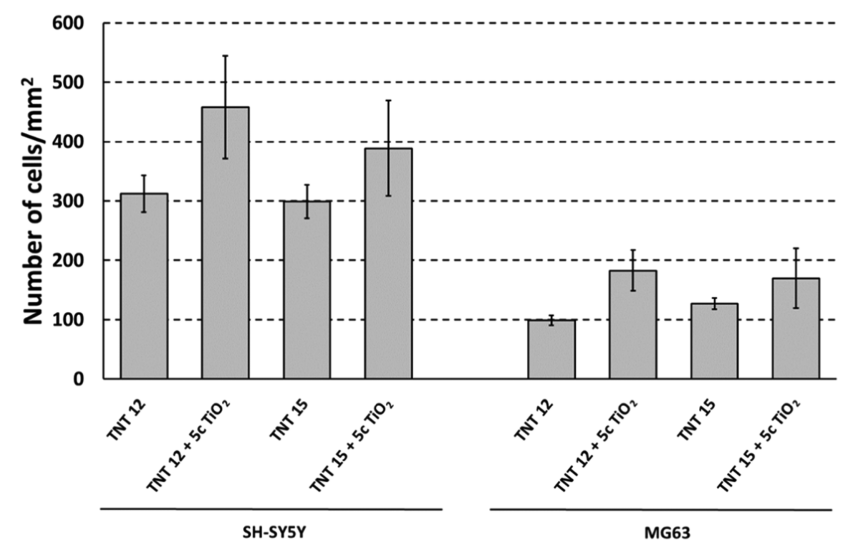

Figure 5. Density of SH-SY5Y and MG-63 cells grown for $24 \mathrm{~h}$ on uncoated and $\mathrm{ALD}$-coated $\left(5 \mathrm{c} \mathrm{TiO}_{2}\right) \mathrm{TiO}_{2}$ nanotube (TNT) layers with inner diameters of 12 and $15 \mathrm{~nm}$ (TNT 12 and TNT 15, respectively). Data are presented as mean \pm SEM.

thickness of the additional ALD $\mathrm{TiO}_{2}$ coating. In the case of an approx. $0.3 \mathrm{~nm}$ thick $\mathrm{TiO}_{2}$ coating, the rearrangement of atoms (i.e., crystallization from amorphous to anatase $\mathrm{TiO}_{2}$ ) is impossible as the anatase crystallites are bigger in size compared to the total thickness of the coating.

It should be mentioned that the original crystalline status of $\mathrm{TiO}_{2}$ in $\mathrm{Ti}$ sheets and TNT layers remained unchanged after
$150 \mathrm{ALD} \mathrm{TiO}_{2}$ cycles, i.e., TNT layers remained amorphous (Figure S10), as verified by side experiments described in the Supporting Information.

Table 1 shows the chemical composition in atomic \% obtained by XPS measurement. Considerable differences in the composition of uncoated and $\mathrm{ALD} \mathrm{TiO}_{2}$-coated $\mathrm{Ti}$ sheets and TNT layers were obtained, particularly in that of the TNT layers. In the $\mathrm{ALD} \mathrm{TiO}_{2}$-coated TNT layers, the amount of $\mathrm{C}$ and $\mathrm{F}$, stemming from air (C species) and from the anodization in fluoride containing a glycerol-based electrolyte (C and F species), decreased, while, simultaneously, the amount of $\mathrm{O}$ and $\mathrm{Ti}$ increased compared to the uncoated TNT layers. This is due to the additional $\mathrm{ALD} \mathrm{TiO}_{2}$ coating shading the $\mathrm{C}$ and $\mathrm{F}$ species. The concentration of $\mathrm{F}$ in TNT layers was decreased 7-9 times after ALD decoration compared to that of the uncoated TNT layers. As XPS is a very sensitive surfaceanalytical technique with an analysis depth only in the nanometer range, a thin compact coating of approx. 0.3 and $8 \mathrm{~nm}$ after 5 and $150 \mathrm{ALD} \mathrm{TiO}_{2}$ cycles, respectively, prevents the detection of other species underneath. The observed increase in the amount of $\mathrm{O}$ and $\mathrm{Ti}$ in ALD-coated samples was due to the high purity of the additional ALD $\mathrm{TiO}_{2}$ coating (i.e., it contains no detectable contaminants). Moreover, the additional compact ALD $\mathrm{TiO}_{2}$ coating prevents the surface contaminants (e.g., $\mathrm{C}$ and $\mathrm{F}$ species) from being potentially in direct contact with the surface/vicinity interface with cells, protects the TNT layers from being crystallized, and prevents 


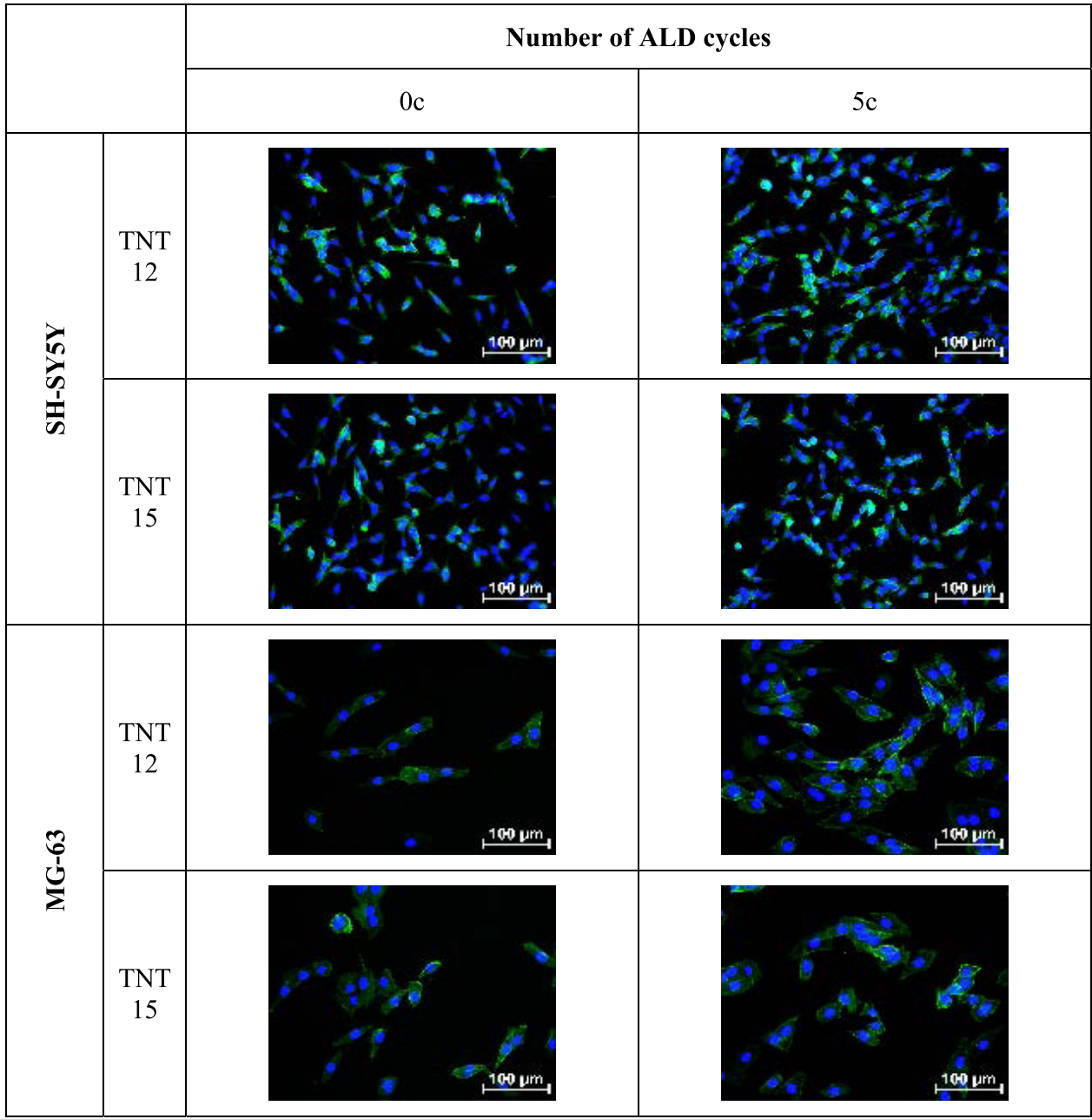

Figure 6. Photomicrographs of SH-SY5Y and MG-63 cells grown for $24 \mathrm{~h}$ on uncoated and ALD-coated (5c $\left.\mathrm{TiO}_{2}\right) \mathrm{TiO}_{2}$ nanotube (TNT) layers with inner diameters of 12 and $15 \mathrm{~nm}$ (TNT 12 and TNT 15, respectively). The cells were stained using the Hoechst 33258 dye (blue, nuclei) and phalloidin-FITC probe (green, actin filaments).

the nanotubes from changing their shape due to the water annealing effect. ${ }^{45}$

\subsection{Cell Behavior on Uncoated and ALD $\mathrm{TiO}_{2}$-Coated} Ti Sheets and TNT Layers. Cell behavior, i.e., adhesion and growth, was evaluated in the response to uncoated and ALD $\mathrm{TiO}_{2}$-coated surfaces of $\mathrm{Ti}$ sheets and TNT layers using fibroblast WI-38 cell line (i.e., counting of cells to quantitate their occurrence per $\left.\mathrm{mm}^{2}\right)$. The particular diameters of TNT layers $(\sim 12 \mathrm{~nm}$, TNT 12 , and $\sim 15 \mathrm{~nm}$, TNT 15$)$ were chosen intentionally. Previous studies ${ }^{42-44}$ reported the cell behavior on TNT layers with the diameter ranging from 15 to $100 \mathrm{~nm}$, where nanotubes with the diameter of $\sim 15 \mathrm{~nm}$ were shown to be optimal for the cell growth of mesenchymal stem cells (MSCs). Additionally, TNT 12 were included in this study as the lowest possible diameter of nanotubes that we could prepare by anodization of a-TiS in a glycerol-based electrolyte. In the case of TNT 12, a nanotubular structure was formed using mild anodization conditions $(2 \mathrm{~V}, 3 \mathrm{~h})$. By lowering the applied voltage during anodization $(<2 \mathrm{~V})$ and/or by decreasing the anodization time $(<3 \mathrm{~h})$, a porous instead of a nanotubular structure was formed.

The WI-38 cell line has been frequently used and is well established for determining the cell growth on different biomaterials' surfaces. ${ }^{53,54}$ As indicated in Figure 3, a significant increase in cell growth after $24 \mathrm{~h}$ of incubation was observed on all ALD $\mathrm{TiO}_{2}$-coated $\mathrm{Ti}$ sheets and TNT layers compared to that of the uncoated ones. In general, the addition of $5 \mathrm{ALD} \mathrm{TiO}_{2}$ cycles was more beneficial for WI-38 cell growth than that of 150 ALD cycles. The results for both ALD sample sets are discussed individually, as follows.

Coating of Ti sheets and TNT layers by 5 ALD $\mathrm{TiO}_{2}$ cycles increased the WI- 38 cell growth by $>50 \%$ compared to that of the uncoated ones. Increased cell growth on these surfaces can be ascribed to the additional thin ALD $\mathrm{TiO}_{2}$ coating (nominal thickness of approx. $0.3 \mathrm{~nm}$ ) that covers the surface of $\mathrm{Ti}$ sheets and TNT layers by a protective $\mathrm{TiO}_{2}$ coating with high purity and strong adhesion to the original surface. Therefore, the naturally occurring surface contaminants on Ti sheets and TNT layers are not in contact with the surface/vicinity interface with cells. In particular, according to reported studies, ${ }^{42,55,56}$ the native F species in TNT layers may inhibit cell growth and proliferation. Moreover, the additional thin ALD $\mathrm{TiO}_{2}$ coating protects TNT layers from crystallization and shape change due to water annealing effect ${ }^{32,45,46}$ and also increases the surface hydrophilicity compared to that of the original surfaces. $^{26,57}$ In general, increased hydrophilicity leads to enhanced cell growth. ${ }^{30,33,58}$ Therefore, increased WI-38 cell growth on Ti sheets and TNT layers after 5c ALD $\mathrm{TiO}_{2}$ can be also ascribed to the enhanced wettability of the surfaces that induced WI-38 cell adhesion and growth. The results 
presented here on the beneficial effect of $5 \mathrm{ALD} \mathrm{TiO}_{2}$ cyclecoated Ti sheets and TNT layers on improved cell growth are significantly advanced compared to those of previous reports, ${ }^{25,26,30}$ where an extremely high number of ALD $\mathrm{TiO}_{2}$ cycles (400-2500) was used to achieve a similar effect. Here, using a much lower number of ALD cycles, the resulting biomaterial exhibited beneficial properties of both the original substrate (Ti sheets and TNT layers) and the additional ALD $\mathrm{TiO}_{2}$ coating. By this effort, the original surface of a-TiS and cTiS was preserved. Unique properties of TNT layers, such as hemocompatibility, great cell adhesion and proliferation, enhanced protein adsorption, improved cellular behavior, and tissue integration, ${ }^{15,38-41}$ were also preserved after 5 ALD $\mathrm{TiO}_{2}$ cycles.

Preservation of both constituents' properties (the unique morphology of the original surface and the protective benefits of the additional ALD $\mathrm{TiO}_{2}$ coating) of any of the herein investigated substrates was not possible when the original surface of it was completely covered by a considerably thick additional ALD $\mathrm{TiO}_{2}$ coating, obtained after 150 ALD cycles (approx. $8 \mathrm{~nm}$ thick compared to approx. $0.3 \mathrm{~nm}$ thin after 5 ALD cycles). Indeed, a significant alteration of the original surface is seen in Ti sheets and TNT layers coated by 150 ALD $\mathrm{TiO}_{2}$ cycles (Figure 1, third column, and Figure S3) and in previous reports. ${ }^{25,26,30}$ In the case of TNT layers, the inner tube diameter decreased substantially and parts of the nanotubes were clogged by the ALD $\mathrm{TiO}_{2}$ coating (Figures II,L and S3). These significant changes in the surface morphology were detrimental for WI-38 cell growth as the biomaterial lost its original advantageous flat (for $\mathrm{Ti}$ sheets) and nanotubular (for TNT layers) morphology. Moreover, the additional $\mathrm{ALD} \mathrm{TiO}_{2}$ coating is crystalline after $150 \mathrm{ALD} \mathrm{TiO}$ cycles compared to the amorphous $\mathrm{TiO}_{2}$ coating after $5 \mathrm{ALD}$ $\mathrm{TiO}_{2}$ cycles. The crystalline status of $\mathrm{TiO}_{2}$ is a crucial factor affecting cell behavior. ${ }^{59,60}$ Nevertheless, contradictory biological responses have been reported for the amorphous and anatase $\mathrm{TiO}_{2}$ surfaces. Previous reports ${ }^{61-63}$ showed improved implant osseointegration on anatase $\mathrm{TiO}_{2}$ surfaces compared to that of amorphous $\mathrm{TiO}_{2}$. On the other hand, mesenchymal stem cells have been reported ${ }^{60,64}$ to exhibit improved cellular activity on amorphous $\mathrm{TiO}_{2}$ surfaces. In general, the differences in cell behavior on amorphous and crystalline $\mathrm{TiO}_{2}$ surfaces depend on the cell type (i.e., primary cells versus cell lines) and different methods employed to assess cellular activities. ${ }^{60}$

Here, the WI-38 cell growth was increased on Ti sheets and TNT layers after coating by $150 \mathrm{ALD} \mathrm{TiO}_{2}$ cycles compared to their uncoated counterparts, but it was not so high compared to the WI-38 cell growth on Ti sheets and TNT layers coated by $5 \mathrm{ALD} \mathrm{TiO}_{2}$ cycles. Similar to the thin $\mathrm{ALD} \mathrm{TiO}_{2}$ coating (after $5 \mathrm{ALD} \mathrm{TiO}_{2}$ cycles), the significantly thicker additional ALD $\mathrm{TiO}_{2}$ coating (after 150 ALD $\mathrm{TiO}_{2}$ cycles) covers the surface contaminants on Ti sheets and TNT layers. This itself has an effect on the increased cell growth and the additional ALD $\mathrm{TiO}_{2}$ coating also protects TNT layers from water annealing. ${ }^{45}$ However, except the change in crystallinity, coating by $150 \mathrm{ALD} \mathrm{TiO}_{2}$ cycles was accompanied by significant morphological changes of $\mathrm{Ti}$ sheets and TNT layers (Figure 1, third column, and Figure S3). The surface of Ti sheets and TNT layers after $150 \mathrm{ALD} \mathrm{TiO}_{2}$ cycles was less favored for cell growth compared to the surface after 5 ALD $\mathrm{TiO}_{2}$ cycles, where the morphology of the original TNT layers was preserved. This comparison between the results obtained for 5 and $150 \mathrm{ALD} \mathrm{TiO}_{2}$ cycles clearly points out that for a given substrate, the composition of the surface compared to the surface roughness has a more important effect on cell growth. Somewhat surprisingly, one exception in this WI-38 cell growth trend was found for TNT $12+150 \mathrm{c} \mathrm{TiO}$, but the difference from TNT $12+5 \mathrm{c} \mathrm{TiO}_{2}$ was not very significant. This difference can be assigned to the combination of optimal surface composition, morphology, and roughness, which as a whole could be slightly more favorable for cell growth in the case of TNT $12+150 \mathrm{c} \mathrm{TiO}{ }_{2}$ compared to TNT $12+5 \mathrm{c} \mathrm{TiO}_{2}$, for this particular tube diameter. Nevertheless, the original unique morphology of nanotubes was lost in TNT $12+150 \mathrm{c}$ $\mathrm{TiO}_{2}$ and the increased cell growth was not substantial (within the error of the mean \pm SEM) compared to that of TNT $12+$ 5c $\mathrm{TiO}_{2}$.

Fluorescence microscopy imaging (Figure 4) of WI-38 cells after $24 \mathrm{~h}$ of incubation was carried out to support the obtained quantitative data (Figure 3). Fluorescence staining of nuclei and actin filaments was used to identify the functional morphology of WI-38 cells. A typical elongated morphology (green) of WI-38 cells was proven. A higher density of nuclei (blue) was observed in Ti sheets and TNT layers coated by 5 and $150 \mathrm{ALD} \mathrm{TiO}_{2}$ cycles compared to that of the uncoated ones. This is in good agreement with the quantitative data obtained in Figure 3.

At last, the cell growth of SH-SY5Y neuroblasts and MG-63 osteoblasts on uncoated and ALD $\mathrm{TiO}_{2}$-coated TNT layers was evaluated. Those cell lines with a different origin and morphology (SH-SY5Y have a stellar shape, while MG-63 have a round shape) were chosen to compare the outcomes from experiments with WI-38 cells of an elongated shape. Only uncoated and ALD 5c $\mathrm{TiO}_{2}$-coated TNT layers were further studied. As the experimental work carried out within this article was already very extensive, the focus was to exploit only the nanotubular surfaces (TNT layers). Moreover, preservation of the unique morphology of nanotubes combined with the enhanced cell growth and the protective properties of the additional $\mathrm{TiO}_{2}$ coating after ALD was very promising and had potential toward advanced biomedical applications. As indicated in Figure 5, the cell growth of SH-SY5Y and MG63 cells after $24 \mathrm{~h}$ of incubation increased by $>30 \%$ on ALD $\mathrm{TiO}_{2}$-coated TNT layers compared to that of the uncoated ones. The difference of the absolute numbers of cell growth occurring per square millimeter of uncoated or ALD $\mathrm{TiO}_{2}$ TNT layers was strongly inversely correlated with a cell size being lowest in SH-SY5Y and largest in MG-63 cells. The results of fluorescence microscopy imaging (Figure 6) of $\mathrm{SH}$ SY5Y and MG-63 support the obtained quantitative data.

\section{CONCLUSIONS}

ALD was exploited to coat $\mathrm{Ti}$ sheets and TNT layers by additional $\mathrm{TiO}_{2}$ thin coatings to improve their biocompatibility for potential medical use. Our results show that coating of these surfaces by only $5 \mathrm{ALD} \mathrm{TiO}_{2}$ cycles resulted in significantly improved cell growth on the Ti sheets and TNT layers surfaces due to morphological, compositional, and structural changes on the corresponding surfaces. The cell growth of WI- 38 fibroblasts was increased by $>50 \%$ on $\mathrm{Ti}$ sheets and TNT layers coated by 5 ALD $\mathrm{TiO}_{2}$ cycles. Moreover, the MG-63 osteoblast and SH-SY5Y neuroblast cell growth was increased by $>30 \%$ on TNT layers coated by 5 ALD $\mathrm{TiO}_{2}$ cycles compared to their uncoated counterparts. 
This novel ALD-based approach offers three distinct advantages: (1) The shown Ti sheets and TNT layers coated by additional thin $\mathrm{ALD} \mathrm{TiO}_{2}$ coating (nominal thickness of approx. $0.3 \mathrm{~nm}$ ) retain their original structure. This is especially demanded for TNT layers with their unique morphology. (2) A thin $\mathrm{ALD} \mathrm{TiO}_{2}$ coating protects the TNT layers from crystallization and shape change due to water annealing and prevents contaminants (naturally occurring on the surface of all materials) from being in direct contact with cells. (3) The risk of delamination of the additional ALD $\mathrm{TiO}_{2}$ coating is avoided due to the nature of the ALD process creating strong chemical bonds between substrates and coatings. The results presented here pave a way for the ALD modification of various $\mathrm{TiO}_{2}$-based and other oxide substrates to increase their biocompatibility and promote cell growth.

\section{ASSOCIATED CONTENT}

\section{(s) Supporting Information}

The Supporting Information is available free of charge at https://pubs.acs.org/doi/10.1021/acsabm.0c00871.

Cross-sectional SEM of TNT layers; detailed SEM topview images of TNT layers; top- and cross-sectional SEM images of uncoated and ALD $\mathrm{TiO}_{2}$-coated TNT layers; DHM roughness profilometry; AFM topographical scans; RMS values determined from AFM scans; low-magnification SEM top-view image of TNT layers; XRD patterns (PDF)

\section{AUTHOR INFORMATION}

\section{Corresponding Authors}

Tomas Rousar - Department of Biological and Biochemical Sciences, Faculty of Chemical Technology, University of Pardubice, 53210 Pardubice, Czech Republic; Phone: +420 466037 707; Email: Tomas.Rousar@upce.cz

Jan M. Macak - Center of Materials and Nanotechnologies, Faculty of Chemical Technology, University of Pardubice, 530 02 Pardubice, Czech Republic; Central European Institute of Technology, Brno University of Technology, 61200 Brno, Czech Republic; (1) orcid.org/0000-0001-7091-3022; Phone: +420 466037 401; Email: Jan.Macak@upce.cz

\section{Authors}

Martin Motola - Center of Materials and Nanotechnologies, Faculty of Chemical Technology, University of Pardubice, 530 02 Pardubice, Czech Republic

Jan Capek - Department of Biological and Biochemical Sciences, Faculty of Chemical Technology, University of Pardubice, 532 10 Pardubice, Czech Republic

Raul Zazpe - Center of Materials and Nanotechnologies, Faculty of Chemical Technology, University of Pardubice, 53002 Pardubice, Czech Republic; Central European Institute of Technology, Brno University of Technology, 61200 Brno, Czech Republic

Jana Bacova - Department of Biological and Biochemical Sciences, Faculty of Chemical Technology, University of Pardubice, 53210 Pardubice, Czech Republic

Ludek Hromadko - Center of Materials and Nanotechnologies, Faculty of Chemical Technology, University of Pardubice, 530 02 Pardubice, Czech Republic; Central European Institute of Technology, Brno University of Technology, 61200 Brno, Czech Republic
Lenka Bruckova - Department of Biological and Biochemical Sciences, Faculty of Chemical Technology, University of Pardubice, 53210 Pardubice, Czech Republic

Siowwoon Ng - Central European Institute of Technology, Brno University of Technology, 61200 Brno, Czech Republic; (1) orcid.org/0000-0003-2176-6710

Jiri Handl - Department of Biological and Biochemical Sciences, Faculty of Chemical Technology, University of Pardubice, 532 10 Pardubice, Czech Republic

Zdenek Spotz - Central European Institute of Technology, Brno University of Technology, 61200 Brno, Czech Republic

Petr Knotek - Department of General and Inorganic Chemistry, Faculty of Chemical Technology, University of Pardubice, 532 10 Pardubice, Czech Republic; $\odot$ orcid.org/0000-0003-24074947

Kaushik Baishya - Central European Institute of Technology, Brno University of Technology, 61200 Brno, Czech Republic

Pavlina Majtnerova - Department of Biological and Biochemical Sciences, Faculty of Chemical Technology, University of Pardubice, 53210 Pardubice, Czech Republic

Jan Prikryl - Center of Materials and Nanotechnologies, Faculty of Chemical Technology, University of Pardubice, 53002 Pardubice, Czech Republic

Hanna Sopha - Center of Materials and Nanotechnologies, Faculty of Chemical Technology, University of Pardubice, 530 02 Pardubice, Czech Republic; Central European Institute of Technology, Brno University of Technology, 61200 Brno, Czech Republic

Complete contact information is available at: https://pubs.acs.org/10.1021/acsabm.0c00871

\section{Notes}

The authors declare no competing financial interest.

\section{ACKNOWLEDGMENTS}

The financial support of the Ministry of Education, Youth and Sports of the Czech Republic via projects NANOBIO (Reg. No. CZ.02.1.01/0.0/0.0/17_048/0007421), NPU I (LQ1601), and CEMNAT RI (LM $\bar{M} 018103)$ is acknowledged. Some XRD and AFM measurements were carried out with the support of CEITEC Nano Research Infrastructure (LM 2018110, MEYS CR, 2020-2022).

\section{REFERENCES}

(1) Niinomi, M. Mechanical Biocompatibilities of Titanium Alloys for Biomedical Applications. J. Mech. Behav. Biomed. Mater. 2008, 3042.

(2) Geetha, M.; Singh, A. K.; Asokamani, R.; Gogia, A. K. Ti Based Biomaterials, the Ultimate Choice for Orthopaedic Implants-A Review. Prog. Mater. Sci. 2009, 54, 397-425.

(3) Lausmaa, J. Surface Spectroscopic Characterization of Titanium Implant Materials. J. Electron Spectrosc. Relat. Phenom. 1996, 81, 343361.

(4) Liu, X.; Chu, P. K.; Ding, C. Surface Modification of Titanium, Titanium Alloys, and Related Materials for Biomedical Applications. Mater. Sci. Eng., R 2004, 47, 49-121.

(5) Hu, X.; Shen, H.; Shuai, K.; Zhang, E.; Bai, Y.; Cheng, Y.; Xiong, X.; Wang, S.; Fang, J.; Wei, S. Surface Bioactivity Modification of Titanium by $\mathrm{CO} 2$ Plasma Treatment and Induction of Hydroxyapatite: In Vitro and in Vivo Studies. Appl. Surf. Sci. 2011, 257, 1813-1823.

(6) Wilson, C. J.; Clegg, R. E.; Leavesley, D. I.; Pearcy, M. J. Mediation of Biomaterial-Cell Interactions by Adsorbed Proteins: A Review. Tissue Eng. 2005, 11, 1-18. 
(7) Teebken, O. E.; Bader, A.; Steinhoff, G.; Haverich, A. Tissue Engineering of Vascular Grafts: Human Cell Seeding of Decellularised Porcine Matrix. Eur. J. Vasc. Endovasc. Surg. 2000, 19, 381-386.

(8) Vorilhon, C.; Massard, C.; Raspal, V.; Sibaud, Y.; Forestier, C.; Charbonnel, N.; Descamps, S.; Awitor, K. O. Feasibility of a Chronic Foreign Body Infection Model Studying the Influ-Ence of $\mathrm{TiO} 2$ Nanotube Layers on Bacterial Contamination. J. Biomater. Nanobiotechnol. 2016, 7, 45-54.

(9) Dolatshahi-Pirouz, A.; Nikkhah, M.; Kolind, K.; Dokmeci, M. R.; Khademhosseini, A. Functional Biomaterials Micro-and Nanoengineering Approaches to Control Stem Cell-Biomaterial Interactions. J. Funct. Biomater. 2011, 2, 88-106.

(10) Song, Y.; Ju, Y.; Song, G.; Morita, Y. In Vitro Proliferation and Osteogenic Differentiation of Mesenchymal Stem Cells on Nanoporous Alumina. Int. J. Nanomed. 2013, 8, 2745-2756.

(11) McKenzie, J. L.; Waid, M. C.; Shi, R.; Webster, T. J. Decreased Functions of Astrocytes on Carbon Nanofiber Materials. Biomaterials 2004, 25, 1309-1317.

(12) Panseri, S.; Cunha, C.; Lowery, J.; Del Carro, U.; Taraballi, F.; Amadio, S.; Vescovi, A.; Gelain, F. Electrospun Micro- and Nanofiber Tubes for Functional Nervous Regeneration in Sciatic Nerve Transections. BMC Biotechnol. 2008, 8, 39.

(13) Khang, D.; Kim, S. Y.; Liu-Snyder, P.; Palmore, G. T. R.; Durbin, S. M.; Webster, T. J. Enhanced Fibronectin Adsorption on Carbon Nanotube/Poly(Carbonate) Urethane: Independent Role of Surface Nano-Roughness and Associated Surface Energy. Biomaterials 2007, 28, 4756-4768.

(14) Webster, T. J.; Waid, M. C.; McKenzie, J. L.; Price, R. L.; Ejiofor, J. U. Nano-Biotechnology: Carbon Nanofibres as Improved Neural and Orthopaedic Implants. Nanotechnology 2004, 15, 48-54.

(15) Webster, T. J.; Ejiofor, J. U. Increased Osteoblast Adhesion on Nanophase Metals: Ti, Ti6Al4V, and CoCrMo. Biomaterials 2004, 25, 4731-4739.

(16) Seil, J. T.; Webster, T. J. Decreased Astroglial Cell Adhesion and Proliferation on Zinc Oxide Nanoparticle Polyurethane Composites. Int. J. Nanomed. 2008, 3, 523-531.

(17) Orsini, G.; Assenza, B.; Scarano, A.; Piattelli, M.; Piattelli, A. Surface Analysis of Machined versus Sandblasted and Acid-Etched Titanium Implants. Int. J. Oral Maxillofac. Implants 2000, 15, 779784.

(18) Jemat, A.; Ghazali, M. J.; Razali, M.; Otsuka, Y. Surface Modifications and Their Effects on Titanium Dental Implants. Biomed. Res. Int. 2015, 2015, 1-11.

(19) Marenzi, G.; Impero, F.; Scherillo, F.; Sammartino, J. C.; Squillace, A.; Spagnuolo, G. Effect of Different Surface Treatments on Titanium Dental Implant Micro-Morphology. Materials 2019, 12, No. 733.

(20) Lee, J.-T.; Cho, S.-A. Biomechanical Evaluation of Laser-Etched Ti Implant Surfaces vs. Chemically Modified SLA Ti Implant Surfaces: Removal Torque and Resonance Frequency Analysis in Rabbit Tibias. J. Mech. Behav. Biomed. Mater. 2016, 61, 299-307.

(21) Qahash, M.; Hardwick, W. R.; Rohrer, M. D.; Wozney, J. M.; Wikesjö, U. M. E. Surface-Etching Enhances Titanium Implant Osseointegration in Newly Formed (RhBMP-2-Induced) and Native Bone. Int. J. Oral Maxillofac. Implants 2007, 22, 472-477.

(22) Kim, H.-W.; Koh, Y.-H.; Li, L.-H.; Lee, S.; Kim, H.-E. Hydroxyapatite Coating on Titanium Substrate with Titania Buffer Layer Processed by Sol-Gel Method. Biomaterials 2004, 25, 25332538.

(23) Shivaram, A.; Bose, S.; Bandyopadhyay, A. Understanding Long-Term Silver Release from Surface Modified Porous Titanium Implants. Acta Biomater. 2017, 58, 550-560.

(24) Yoshinari, M.; Oda, Y.; Inoue, T.; Matsuzaka, K.; Shimono, M. Bone Response to Calcium Phosphate-Coated and BisphosphonateImmobilized Titanium Implants. Biomaterials 2002, 23, 2879-2885.

(25) Nazarov, D.; Zemtsova, E.; Valiev, R.; Smirnov, V. Formation of Micro- and Nanostructures on the Nanotitanium Surface by Chemical Etching and Deposition of Titania Films by Atomic Layer Deposition (ALD). Materials 2015, 8, 8366-8377.
(26) Liu, L.; Bhatia, R.; Webster, T. J. Atomic Layer Deposition of Nano-TiO2 Thin Films with Enhanced Biocompatibility and Antimicrobial Activity for Orthopedic Implants. Int. J. Nanomed. 2017, 12, 8711-8723.

(27) Hsu, L. C.; Lan, W. C.; Ou, K. L.; Chou, H. H.; Wen, S. C.; Liu, C. M.; Endo, K.; Huang, M. S.; Huang, C. F. Fabrication of Biomolecules Coated Nanostructured Oxide Layer to Facilitate Cell Adhesion and Proliferation for Improving Osseointegration. Ceram. Int. 2019, 45, 21941-21946.

(28) Yang, Q.; Yuan, W.; Liu, X.; Zheng, Y.; Cui, Z.; Yang, X.; Pan, $\mathrm{H}$.; Wu, S. Atomic Layer Deposited ZrO2 Nanofilm on Mg-Sr Alloy for Enhanced Corrosion Resistance and Biocompatibility. Acta Biomater. 2017, 58, 515-526.

(29) Yao, L.; Wu, X.; Wu, S.; Pan, X.; Tu, J.; Chen, M.; Al-Bishari, A. M.; Al-Baadani, M. A.; Yao, L.; Shen, X.; Liu, J. Atomic Layer Deposition of Zinc Oxide on Microrough Zirconia to Enhance Osteogenesis and Antibiosis. Ceram. Int. 2019, 45, 24757-24767.

(30) Nazarov, D. V.; Smirnov, V. M.; Zemtsova, E. G.; Yudintceva, N. M.; Shevtsov, M. A.; Valiev, R. Z. Enhanced Osseointegrative Properties of Ultra-Fine-Grained Titanium Implants Modified by Chemical Etching and Atomic Layer Deposition. ACS Biomater. Sci. Eng. 2018, 4, 3268-3281.

(31) Radtke, A.; Ehlert, M.; Jędrzejewski, T.; Sadowska, B.; Więckowska-Szakiel, M.; Holopainen, J.; Ritala, M.; Leskelä, M.; Bartmański, M.; Szkodo, M.; Piszczek, P. Titania Nanotubes/ Hydroxyapatite Nanocomposites Produced with the Use of the Atomic Layer Deposition Technique: Estimation of Bioactivity and Nanomechanical Properties. Nanomaterials 2019, 9, No. 123.

(32) Wang, D.; Liu, L.; Zhang, F.; Tao, K.; Pippel, E.; Domen, K. Spontaneous Phase and Morphology Transformations of Anodized Titania Nanotubes Induced by Water at Room Temperature. Nano Lett. 2011, 11, 3649-3655.

(33) Motola, M.; Dworniczek, E.; Satrapinskyy, L.; Chodaczek, G.; Grzesiak, J.; Gregor, M.; Plecenik, T.; Nowicka, J.; Plesch, G. UV Light-Induced Photocatalytic, Antimicrobial, and Antibiofilm Performance of Anodic TiO 2 Nanotube Layers Prepared on Titanium Mesh and Ti Sputtered on Silicon. Chem. Pap. 2019, 73, 1163-1172.

(34) Macak, J. M.; Tsuchiya, H.; Ghicov, A.; Yasuda, K.; Hahn, R.; Bauer, S.; Schmuki, P. TiO2 Nanotubes: Self-Organized Electrochemical Formation, Properties and Applications. Curr. Opin. Solid State Mater. Sci. 2007, 11, 3-18.

(35) Lai, S.; Zhang, W.; Liu, F.; Wu, C.; Zeng, D.; Sun, Y.; Xu, Y.; Fang, Y.; Zhou, W. TiO2 Nanotubes as Animal Drug Delivery System and In Vitro Controlled Release. J. Nanosci. Nanotechnol. 2013, 13, 91-97.

(36) Popat, K. C.; Eltgroth, M.; LaTempa, T. J.; Grimes, C. A.; Desai, T. A. Titania Nanotubes: A Novel Platform for Drug-Eluting Coatings for Medical Implants? Small 2007, 3, 1878-1881.

(37) Wu, S.; Weng, Z.; Liu, X.; Yeung, K. W. K.; Chu, P. K. Functionalized $\mathrm{TiO}_{2}$ Based Nanomaterials for Biomedical Applications. Adv. Funct. Mater. 2014, 24, 5464-5481.

(38) Yao, C.; Storey, D.; Webster, T. J. Nanostructured Metal Coatings on Polymers Increase Osteoblast Attachment. Int. J. Nanomed. 2007, 2, 487-492.

(39) Webster, T. J.; Ercan, B.; Balasubramanian, K.; Webster, T. J. Reduced Adhesion of Macrophages on Anodized Titanium with Select Nanotube Surface Features. Int. J. Nanomed. 2011, 6, 1765.

(40) Simchi, A.; Tamjid, E.; Pishbin, F.; Boccaccini, A. R. Recent Progress in Inorganic and Composite Coatings with Bactericidal Capability for Orthopaedic Applications. Nanomedicine 2011, 7, 2239.

(41) von Wilmowsky, C.; Bauer, S.; Roedl, S.; Neukam, F. W.; Schmuki, P.; Schlegel, K. A. The Diameter of Anodic TiO2 Nanotubes Affects Bone Formation and Correlates with the Bone Morphogenetic Protein-2 Expression in Vivo. Clin. Oral Implants Res. 2012, 23, 359-366.

(42) Park, J.; Bauer, S.; Schmuki, P.; von der Mark, K. Narrow Window in Nanoscale Dependent Activation of Endothelial Cell 
Growth and Differentiation on $\mathrm{TiO}_{2}$ Nanotube Surfaces. Nano Lett. 2009, 9, 3157-3164.

(43) Bauer, S.; Park, J.; Faltenbacher, J.; Berger, S.; Von Der Mark, K.; Schmuki, P. Size Selective Behavior of Mesenchymal Stem Cells on $\mathrm{ZrO} 2$ and $\mathrm{TiO} 2$ Nanotube Arrays. Integr. Biol. 2009, 1, 525-532.

(44) Park, J.; Bauer, S.; Schlegel, K. A.; Neukam, F. W.; von der Mark, K.; Schmuki, P. TiO 2 Nanotube Surfaces: 15 Nm-An Optimal Length Scale of Surface Topography for Cell Adhesion and Differentiation. Small 2009, 5, 666-671.

(45) Ng, S.; Sopha, H.; Zazpe, R.; Spotz, Z.; Bijalwan, V.; Dvorak, F.; Hromadko, L.; Prikryl, J.; Macak, J. M. TiO2 ALD Coating of Amorphous $\mathrm{TiO} 2$ Nanotube Layers: Inhibition of the Structural and Morphological Changes Due to Water Annealing. Front. Chem. 2019, 7, $1-12$.

(46) Liao, Y.; Que, W.; Zhong, P.; Zhang, J.; He, Y. A Facile Method to Crystallize Amorphous Anodized $\mathrm{TiO} 2$ Nanotubes at Low Temperature. ACS Appl. Mater. Interfaces 2011, 3, 2800-2804.

(47) Sopha, H.; Krbal, M.; Ng, S.; Prikryl, J.; Zazpe, R.; Yam, F. K.; Macak, J. M. Highly Efficient Photoelectrochemical and Photocatalytic Anodic $\mathrm{TiO} 2$ Nanotube Layers with Additional $\mathrm{TiO} 2$ Coating. Appl. Mater. Today 2017, 9, 104-110.

(48) Sopha, H.; Tesar, K.; Knotek, P.; Jäger, A.; Hromadko, L.; Macak, J. M. TiO2 Nanotubes Grown on Ti Substrates with Different Microstructure. Mater. Res. Bull. 2018, 103, 197-204.

(49) Pilling, N. B.; Bedworth, R. E. The Oxidation of Metals. J. Inst. Met. 1923, 529-581.

(50) Lee, K.; Mazare, A.; Schmuki, P. One-Dimensional Titanium Dioxide Nanomaterials: Nanotubes. Chem. Rev. 2014, 8, 9385-9454.

(51) Zhang, H.; Banfield, J. F. Phase Transformation of Nanocrystalline Anatase-to-Rutile via Combined Interface and Surface Nucleation. J. Mater. Res. 2000, 15, 437-448.

(52) Motola, M.; Hromadko, L.; Prikryl, J.; Sopha, H.; Krbal, M.; Macak, J. M. Intrinsic Properties of High-Aspect Ratio Single- and Double-Wall Anodic TiO2 Nanotube Layers Annealed at Different Temperatures. Electrochim. Acta 2020, 352, No. 136479.

(53) Liu, T. L.; Miao, J. C.; Sheng, W. H.; Xie, Y. F.; Huang, Q.; Shan, Y. B.; Yang, J. C. Cytocompatibility of Regenerated Silk Fibroin Film: A Medical Biomaterial Applicable to Wound Healing. J. Zhejiang Univ. Sci. B 2010, 11, 10-16.

(54) Tree-Udom, T.; Seemork, J.; Shigyou, K.; Hamada, T.; Sangphech, N.; Palaga, T.; Insin, N.; Pan-In, P.; Wanichwecharungruang, S. Shape Effect on Particle-Lipid Bilayer Membrane Association, Cellular Uptake, and Cytotoxicity. ACS Appl. Mater. Interfaces 2015, 7, 23993-24000.

(55) Gu, X.; Han, D.; Chen, W.; Zhang, L.; Lin, Q.; Gao, J.; Fanning, S.; Han, B. SIRT1-Mediated FoxOs Pathways Protect against Apoptosis by Promoting Autophagy in Osteoblast-like MC3T3-E1 Cells Exposed to Sodium Fluoride. Oncotarget 2016, 7, $65218-65230$.

(56) Bergandi, L.; Aina, V.; Malavasi, G.; Morterra, C.; Ghigo, D. The Toxic Effect of Fluoride on MG-63 Osteoblast Cells Is Also Dependent on the Production of Nitric Oxide. Chem. Biol. Interact. 2011, 190, 179-186.

(57) Abdulagatov, A. I.; Orudzhev, F. F.; Rabadanov, M. K.; Abdulagatov, I. M. Copper Nanowire Arrays Surface Wettability Control Using Atomic Layer Deposition of TiO2. Russ. J. Appl. Chem. 2016, 89, 1265-1273.

(58) Dawson, E.; Mapili, G.; Erickson, K.; Taqvi, S.; Roy, K. Biomaterials for Stem Cell Differentiation. Adv. Drug Delivery Rev. 2008, 14, 215-228.

(59) Hong, Y.; Yu, M.; Lin, J.; Cheng, K.; Weng, W.; Wang, H. Surface Hydroxyl Groups Direct Cellular Response on Amorphous and Anatase TiO2 Nanodots. Colloids Surf., B 2014, 123, 68-74.

(60) Park, J.; Bauer, S.; Schmuki, P.; Von Der Mark, K. Narrow Window in Nanoscale Dependent Activation of Endothelial Cell Growth and Differentiation on TiO2 Nanotube Surfaces. Nano Lett. 2009, 9, 3157-3164.

(61) Li, L. H.; Kong, Y. M.; Kim, H. W.; Kim, Y. W.; Kim, H. E.; Heo, S. J.; Koak, J. Y. Improved Biological Performance of $\mathrm{Ti}$
Implants Due to Surface Modification by Micro-Arc Oxidation. Biomaterials 2004, 25, 2867-2875.

(62) Oh, S.; Daraio, C.; Chen, L. H.; Pisanic, T. R.; Fiñones, R. R.; Jin, S. Significantly Accelerated Osteoblast Cell Growth on Aligned TiO2 Nanotubes. J. Biomed. Mater. Res., Part A 2006, 78, 97-103.

(63) Sollazzo, V.; Pezzetti, F.; Scarano, A.; Piattelli, A.; Massari, L.; Brunelli, G.; Carinci, F. Anatase Coating Improves Implant Osseointegration In Vivo. J. Craniofac. Surg. 2007, 18, 806-810.

(64) Park, J.; Bauer, S.; Von Der Mark, K.; Schmuki, P. Nanosize and Vitality: TiO2 Nanotube Diameter Directs Cell Fate. Nano Lett. 2007, 7, 1686-1691. 